\title{
Linking Library Profession and the Market Place: Finding Connections for the Library in the Digital Environment
}

\author{
Behdja Boumarafi \\ Institute of Library and Documentation, University of Constantine 2, Algeria
}

Copyright $(2016$ by authors, all rights reserved. Authors agree that this article remains permanently open access under the terms of the Creative Commons Attribution License 4.0 International License

\begin{abstract}
The fast-paced changing information environment calls for continual development of libraries and information institutions to cope with the changes of the digital environment. To ensure this, there is a need to understand the current employment trends to identify the competencies and skills required of professionals. The advent of information and communication technology (ICT) has created a real paradigm shift in Library operations so information professionals are working at the leading edge of the internet and the web technology; leading to more web-based services. Moreover, the digital environment is reshaping the whole context within which information is being generated, processed, and delivered through online networks. This has strategic significance for library professionals in facing the challenges of this ever-changing information environment in which ICT is the major source for survival and development. This is having a direct impact on library development; a development which is reflected in the literature as required by the emerging market place. The inevitable consequences for professionals are to be equipped with the necessary skills, traits and competencies applicable to the cyber environment to meet the demands of the ever changing job market. The paper identifies the characteristics required of library and information (LIS) workers to serve the expanding and changing information market of the $21^{\text {st }}$ century, as reflected in job announcements posted on the listserv of the IFLA from January to October 2014 to create a synergy between the profession and the current employment trends. A sample set of 259 job advertisements posted by academic, public and special libraries are selected and are grouped in four categories these are: 1. Technology-based positions with $48.71 \%$ of the advertisements. 2. Public/information services skills listed by $22.87 \%$ of the openings. 3. Technical services skills scored $18.64 \%$ of the available jobs. 4. Personal attributes are mentioned in 9.74\% positions. Most positions are available in Academic libraries.
\end{abstract}

Keywords Job Announcements, Job Advertisements,
Job Openings, Library/Information Employers, Employment Trends, Digital Environment, Information Professionals, Library Work-force

\section{Introduction}

At the dawn of knowledge-economy, library and information profession experienced a significant shift as a result of ongoing technological developments. The widespread use of information and communication technology (ICT) and its applications have brought about radical changes in LIS landscape well as a user-base diversification. These developments had a direct impact on the preparation of the information workforce. Libraries and information institutions have undergone enormous changes in recent years to operate effectively in the digital environment. Hence, a new information model has evolved to meet the demands of the new millennium where the serves as a primary nucleus. As ICT continues to penetrate libraries activities and methods, professionals and academics began to consider how to link the profession to the market place to fully integrate in and embrace changes generated by the digital environment. These changes resulted in the following:

- Heavy use and reliance on new technology

- Workforce competency shift

- Expanded LIS market place

- Greater expectations from employers

- Sophisticated patron needs

- Change of information seeking and use patterns

This has strategic significance for library professionals in facing the challenges of this ever-changing information environment in which ICT is the major source for survival and development. As the digital world continues to evolve, the scholarly discussion began to consider how library and 
information science (LIS) education programs can be developed to prepare graduates for the employment trends of the digital environment. So, there is a need to understand the current employment trends to identify the competencies and skills required of employees. LIS professionals are working at the leading edge of the internet and the web technology; leading to more web-based services. Moreover, the digital environment is reshaping the whole context within which information is being generated, processed, and delivered through online networks to ensure ubiquitous information provision. This will enhance the flow of information with a flexibility of time and pace of delivery.

Nowadays LIS graduates are facing a new competition by a new breed of information workers and also they no longer seem to be the first choice of employers in the information sector. They are competing with graduates from a variety of other disciplines such as computer science, business, management, communication among others for job opportunities. As a result, there are pressures to increase the role of information workers to respond to this challenge by securing a presence in the digital environment. This has provoked a wide-range of debate about what kind of competencies and knowledge LIS graduates need to improve career options. There are workplace competencies such as innovative ICT skills, problem-solving skills, ability to work in teams, interpersonal skills, language skills among others are more solicited by potential employers.

The paper examines job announcements posted on the listserv of the International Federation of Library Associations (IFLA) LIBJOBS from January to October 2014 to identify skills, knowledge and competencies required by employers. It is expected that the analysis of the identified announcements will lay the groundwork for exponential growth of LIS education programs to meet the new employment trends. A list of 259 new jobs picked from the mentioned site will serve for analysis.

A literature on library job announcements and new employment trends is briefly described and used as a framework for analysis of the findings of the present study. The idea is to provide an indication of the current market demands that will help LIS educators create a synergy between the classroom and the market needs. It is also hoped that the results of this study will help establish a platform that can achieve compatibility between LIS education and practice as required by employers.

\section{Objectives of the Study}

This study is undertaken to accomplish the following objectives:

- Use LIS job announcements to identify trends in the employment market.

- Identify specific skills, knowledge and competencies sought by potential employers in their job announcements.

- Provide an indication of the employment trends through which LIS curricula can be developed to meet the needs of the $21^{\text {st }}$ century digital market place.

\section{Literature Review}

There is an extensive documented literature on LIS job announcements over the years. Most of the literature concentrated on the requirements of the emerging market in the light of ICT penetration in library work as well as the advanced skills, knowledge and competencies that a library/information professional should have to fully integrate in the digital environment and broaden his/her career prospects.

According to Starr (2004) online job advertisements are providing a clear picture of the job market. Beile and Adams (2000) in their analysis of job advertisements found a decrease in the demand for catalogers due to outsourcing and copy-cataloging in practice by libraries. They also revealed that system positions are filled by non LIS graduates. Reeves and Hahn (2010) analyzed the current state of the job market for LIS graduates in the United States. The authors analyzed the content of 1042 job advertisements; they found that two third of the advertised positions that is $63.3 \%$ were in academic libraries, $13 \%$ in public library sector and only $5.4 \%$ in special libraries. The study also revealed that $(40 \%)$ of all advertised positions were for public services mainly in reference, instruction and access services. This suggests that courses related to those areas must get the attention of LIS educators to give new graduates of improving job opportunities in those areas. The authors also found that $31.4 \%$ of the jobs were in technical services. This is an indication that catalogers and other technical operations are still popular in libraries, contrary to what Beile and Adams contended. Only 5.2\% for systems; this may be a result that employers look for graduates of other disciplines namely computer science, management information systems and the like to fill the system's position in libraries. Employers are also looking for experience and skills in communication, service orientation, collaboration and team work. Also to qualify for the job, the LIS graduate should have some personal traits such as ability to adapt to change, to meet deadlines, to innovate, and to take initiatives.

There are a number of studies that analyzed job announcement for entry-level graduates. For instance, Sproles and Ratledge (2004) analyzed 1500 advertisements focusing on reference and systems' positions, to identify which skills, knowledge and abilities employers are seeking in fresh graduates. The study showed evidence of the need for experience in addition to a Master degree. This finding was enforced by Holt and Strock's (2005) study which revealed that employers demanded experience. This has significance for the module of internship which is included in LIS curricula to give students the possibility of experiencing real-world situations and give them a better chance in their application for jobs. In retrospect, the new employee will be able produce tangible evidence of 
strengthening the relationship between LIS educators and potential employers.

Analyzing 129 job ads in Irish newspapers, Cullen (2000) found that IT skills and interpersonal \& communication skills were in high demand in Irish libraries. Croneis and Henderson (2002) focused on positions related to digital competencies announced in the College \& Research Libraries News. Marion (2001) analyzed 250 job announcements for academic libraries found that technical skills, interpersonal skills $\&$ behavioral skills are required for most positions.

Partridge et al. (2010) used focus groups aimed at identifying the skills, knowledge and attributes required by the emerging information market in Australia. The discussion focused on the type of LIS professionals the web2.0 requires. The authors observed that the web 2.0 has more to do with attitudes and traits than it does with technology. King's (2007) study rather emphasized the importance of information technology (IT) skills needed in the web 2.0 environment including ability to use blogs, podcasts and screen casts, create a short video and upload photos, select and use a new IT devices. Mathews and Pardue (2009) also found that IT skills for information professionals are necessary in the new information era. In his description of core competencies for the emerging job market, Feng (2005) portrays the image of a new generation librarian; librarian 2.0 as an information enabler and knowledge creator with fluency in web languages such as HTML, Flash and XAML, teaching ability, e-learning experience, ability to apply web 2.0, a driver for competitive intelligence, ability to understand the regulatory conditions of the market. Along the same lines, Aharony (2008) claims that librarian 2.0 connects users to experts and community of practice, develops social networks, encourages the development of content and metadata and uses blogs and wikis for the end users' benefit. The author explored the extent to which web 2.0 is taught in 59 LIS programs in America found that only three programs offered full courses in web 2.0 and a few of them included issues related to web 2.0 in their IT courses. Some programs are planning to offer such courses in the future and others do not offer any course on web 2.0. So the author concluded that LIS schools in the United States do not seem to realize the importance of the changing and dynamic innovations that are taking place around them. In another context, Bin Hashim and Wan Mokhtar (2005) suggested that successful information professionals will be those who have management and interpersonal skills, can create web pages, select library management system, take up intranet projects, manage knowledge, and offer web-based instruction and tutorials. A seminal study conducted by Rehman and Ansari (2003) to assess the potential of six LIS programs in the Arabian Gulf countries in response to the expanding digital market. The authors reported little change in the curricula that reflect the global expanding information market created by the digital environment. The study pointed out concerns regarding the programs offered in the region and concluded that these programs demanded significant changes in the curricula content, faculty research activities, and information technology resources and facilities to be able to cope with the digital environment of the $21^{\text {st }}$ century.

In summary, the literature review revealed a debate that focused on two particular themes i) the new trends in the marketplace practices and ii) the stress on a certain set of skills and competencies that are needed by potential employers.

This study seeks to identify new skills and competencies that are required of the $21^{\text {st }}$ century information professionals by analyzing job announcements and making recommendations about how LIS programs can prepare graduates for the digital environment.

\section{Methodology}

Using job announcements is an established method of identifying what potential employers consider important when hiring staff. This study reports the results of job announcements analysis over ten months. The data of the study consists of 259 positions posted on the listserv of the International Federation of Library Associations (IFLA) LIBJOBS from January to October 2014. LIBJOBS is an online job posting used by employers and job seekers in the field of libraries and information. The study included job announcements that specifically asked for library and information professional qualification from an ALA accredited institution or equivalent and full time positions regardless of location of the job. Demands for technicians were not included in the study. Also print announcements were not used to collect data. Senior management positions such as dean/director, associate dean/director were also excluded from the study as these are classified as library administrators/managers not as professional information workers.

Content analysis of the job announcements was then conducted to determine what skills, knowledge and competencies are requested by the emerging information job market. The analysis identified specific requirements in each announcement. The frequency of the skill or knowledge or competency was checked across the sample set of 259 jobs. Once selected the job positions were put under four categories as shown in table 1 . The job announcements were concerned with academic, public and special libraries only. Other types of libraries such as those in international and national organizations, museums and government departments were not included. School libraries were also excluded because all openings asked either for a part time or a technician staff and these are not the focus of this study.

\section{Results}

All job announcements demanded a master of LIS from an 
ALA accredited institution or equivalent. Knowledge of a second European language was desired by a number of announcements. Oral and written communication as well as work experience required in specific functional areas of libraries was present in all announcements. A number of social skills and personal attributes were required by all job announcements.

The positions were grouped in specific set of skills, knowledge and competencies. Four specific job categories were identified along with required skills for each category as shown in table 1 .

Table 1. Job categories classification and required skills

\begin{tabular}{|c|c|c|}
\hline \multicolumn{2}{|r|}{ Job categories } & Required skills \\
\hline 1 & $\begin{array}{l}\text { Technology -based } \\
\text { services positions }\end{array}$ & $\begin{array}{l}\text { Programming, hardware and software } \\
\text { evaluation, Management of library } \\
\text { system; troubleshooting, maintaining, } \\
\text { upgrading, creating and maintaining } \\
\text { webpage, graphic interface, } \\
\text { web-language skills, digital services, } \\
\text { Microsoft office suite. }\end{array}$ \\
\hline 2 & $\begin{array}{c}\text { Public/information } \\
\text { services positions }\end{array}$ & $\begin{array}{l}\text { Teaching skills, information literacy, } \\
\text { needs analysis and negotiation, service } \\
\text { creation \& delivery, distance services, } \\
\text { database searching, reference, } \\
\text { information retrieval, customer services, } \\
\text { on site and remote access services, } \\
\text { e-tutorial skills. }\end{array}$ \\
\hline 3 & $\begin{array}{l}\text { Technical services } \\
\text { positions }\end{array}$ & $\begin{array}{l}\text { Use of standards, bibliographic utilities, } \\
\text { traditional and digital collection } \\
\text { management, metadata, serial } \\
\text { management, metadata creation, } \\
\text { cataloging and archiving websites }\end{array}$ \\
\hline 4 & Personal attributes & $\begin{array}{l}\text { Interpersonal skills, Communication } \\
\text { skills, a foreign language, team work, } \\
\text { outreach, negotiating skills, legal savvy, } \\
\text { analytical skills }\end{array}$ \\
\hline
\end{tabular}

The frequency occurrence of each position was calculated manually and used to rank the job categories from 1-4. Jobs by types of libraries fell in three categories namely academic, public and special libraries. A summary of job occurrences of each category is presented in table 2 .

Table 2. Job occurrences by category.

\begin{tabular}{|c|c|c|c|}
\hline \multicolumn{2}{|c|}{ Job categories } & $\begin{array}{c}\text { Number of } \\
\text { positions }\end{array}$ & Percentage \\
\hline 1 & $\begin{array}{c}\text { Technology-based } \\
\text { services positions }\end{array}$ & 115 & 48.71 \\
\hline 2 & $\begin{array}{c}\text { Public/information } \\
\text { services positions }\end{array}$ & 77 & 22.87 \\
\hline 3 & $\begin{array}{c}\text { Technical services } \\
\text { positions }\end{array}$ & 44 & 18.64 \\
\hline 4 & Personal attributes & 23 & 9.74 \\
\hline \multicolumn{2}{|c|}{ Total } & 259 & 99.96 \\
\hline
\end{tabular}

As evidenced by the job occurrences in table (2), positions related to Information technology services seem to be most wanted by employers with 115 (48.71\%) announcements partly as a result of workplace change which requires competency shift and partly because in today's K-society ICT skills and knowledge are more necessary than ever before. Also, the literature makes it clear that ICT skills are necessary for LIS graduates to face the challenges of the $21^{\text {st }}$ century emerging market. Digital and web related skills and language are in high demand. This has implications for LIS programs that are called upon to equip graduates with the knowledge and tools to develop content for internet and intranet, create and maintain webpage, use graphic interface, web-language, and digital collection. System librarian is a segment that had lower openings as it was mentioned only few times. The most likelihood is that employers are either filling this position with none LIS graduates, or advertising it in other websites and/or sources (newspapers for example).77 (22.87) openings in public services are user-centric involving instruction/teaching skills necessary for training users, using e-learning systems for on site and distant instruction. This is not surprising since increasingly, librarians especially in the academic environment are designing and delivering information literacy courses and online tutorials, sometimes in collaboration with faculty to support users' lifelong learning, so it is expected to see that employers asked for instruction skills. Needs analysis and negotiation, service creation \& delivery, are also in demand by the market place. However, fewer jobs seem to be needed for information searching and retrieval. This may be attributed to the fact that today's users or what is known as Internet generation possess the generic information skills so they are doing much of the work related to information searching and retrieval themselves without the help of the information services staff. Nevertheless, this should not imply that information service- related work is no more an important job; it may not have been in high demand during the period of the data collection for the study. Positions in technical services occurred 44 times (18.64\%) where employers were asking specifically for heads of technical services or head of cataloging division as well as digital collection management and metadata creation. Personal attributes are mentioned in $23(9.74 \%)$ positions this may not be a common requirement in libraries at the time of this study.

ICT has impacted the instruction and learning activities in universities with the view of the student as an active player engaged in his/her learning. At this junction, librarians especially in the academic environment are designing and delivering information literacy courses and online tutorials, sometimes in collaboration with faculty to support lifelong learning to fully integrate in the evolving instruction and learning model. So it is expected to see that employers asked for instruction skills. These new market place requirements have far reaching implications for LIS programs as well as the workforce required for the changing information market. A critical importance of grappling with this market is to incorporate its needs into the curriculum.

The number of positions by type of library is presented in table 3 . 
The results in table 3 show that jobs available in academic libraries comprised almost half of the announcements with $124(47.87 \%)$ of the total job openings. Job seekers who are interested in academic libraries have better chances of getting a position. The next library that scored high job announcements is the public library with 75 (28.95\%) positions. This may be attributed to the fact that the study included in the analysis only the job ads that specified the word "public library". Libraries in archive center and museums were excluded from the analysis as mentioned earlier in the methodology. The relatively low number of jobs is available in special libraries representing $60(23.16 \%)$. This could be the result that the study considered openings that specifically mentioned in the advertisement "special library" as a designation.

Table 3. Jobs by types of libraries

\begin{tabular}{|c|c|c|}
\hline Library type & Number of jobs & percentage \\
\hline Academic library & 124 & 47.87 \\
\hline Public library & 75 & 28.95 \\
\hline Special library & 60 & 23.16 \\
\hline Total & 259 & 99.98 \\
\hline
\end{tabular}

\section{Discussion}

All job announcements demanded a master degree from and an ALA accredited institution or equivalent. Also, experience varying in years was present in all job announcements. Employers are clearly looking to hire staff with technologically savvy skills. Information and communication technology is the most requested skill regardless of the library type. Certainly, the $21^{\text {st }}$ century information professionals are expected not only to possess the generic IT skills but also to be able to use advanced technology such as digital and metadata and web design technology with fluency in web languages and related skills that were much apparent in the announcements. So it is imperative that LIS schools take cognizance of such requirements in order to produce a manpower well equipped with the proper ICT knowledge and skills. LIS graduates are expected to design and teach information literacy programs and deliverer them using traditional means as well as e-learning systems and create tools for instruction on site and remotely. This is coming repeatedly in openings in university libraries. These are logical results of the technological environment in which most libraries are operating and more specifically those attached to academic institutions. Besides, it is a requirement for life-long learning that professional institutions are demanding that information institutions deliver to their user in ILP (information literacy programs). Interpersonal skills are clearly in demand. This means that future information employees have to have appropriate social skills to deal with different user groups. But a skill apparently less important is customer services as it is less emphasized in the openings. This is likely due to overlapping of information services/customer services that includes dealing with users in other words library customers. In that, many jobs listed as information services involve customer services and vice-versa. Half of the positions are available in academic libraries so graduates interested in this type of libraries will find more employment opportunities than their counterparts interested in public and special libraries. Also, a number of new job titles appeared in the announcements such as for instance Web coordinator, programmer, and content management, project management among others. By and large, this study brought to LIS educators' attention the essential facts necessary for understanding the information environment that led to a paradigm shift in the profession. This must be reflected in LIS programs to show their relevance to the digital era. Finally the question is how the changes in the market place be translated into course contents to satisfy potential employers. A logical approach to the answer is a close collaboration between LIS schools and all stakeholders in the information environment.

\section{Recommendations}

In light of these findings LIS educators should revise and develop their curricula to give students the opportunity to acquire the skills needed to prepare for a good library career. Therefore, the following actions could be taken by LIS schools:

- Collaborate with potential employers in the curriculum development to ensure that their graduates are well equipped to meet the requirements of the emerging job market.

- Emphasize the use of ICT in the classroom to offer students advanced technical know-how by using and manipulating the advanced technology.

- Ensure that group work, presentations, role play and seminars are integrated into the classroom activities to help students develop interpersonal and social skills.

- Focus on class presentations so that students can develop teaching skills to use in ILP sessions.

- Offer ample opportunities for internship and on-the-job training in which students can work in teams, develop communication, customer-service skills and gain some work experience to be job ready.

Some of the skills and competencies that are most frequently demanded by employers may be difficult to teach in a classroom setting such as customer services that involves attributes like interpersonal skills, user-centric, personal characteristics and so on. Nevertheless, LIS educators can examine the job descriptions of the announcements to get clear ideas of what to bring to the classroom to prepare graduates for the market place. They 
can also invite employers to deliver talks and seminars in order to express their needs to students.

\section{Conclusions}

The knowledge society is here, and libraries are operating in a digital environment so the $21^{\text {st }}$ century LIS graduates need to have the skills, knowledge and competencies that increase their employment prospects in it. The study sought to identify the requirements of the emerging information market so as to incorporate them into the LIS curricula. Four specific job categories were found. Analysis of these job announcements provides some evidence of job availability for LIS graduates (during the period the study was carried out). But, only those with significant skills and knowledge in general and advanced technology would qualify for a job. Qualified graduates need to look for jobs in the academic library sector as a smaller number of jobs were found in public and special libraries. Very few jobs are available for those interested in specific functional areas, particularly in Systems, archives and record management. Employers are looking for graduates who not only have the knowledge and experience, but also interpersonal skills such as communication skills, service orientation, team work, innovation, and creativity. This study along with previous studies underscores the need for curriculum revision to prepare LIS graduates for the $21^{\text {st }}$ LIS job market. This can be done properly with the collaboration of potential employers.

\section{REFERENCES}

[1] Aharony, N. (2008), "Web 2.0 in U.S. Schools: Are they Missing the Boat". Available at: http://www.ariadne.ac.uk/is sue54/aharony/ accessed November 2013.

[2] Beile, P.M. and Adams, M.M. (2000), "Other as Assigned: Emerging Trends in the Academic Library Job Market". College and Research Libraries, vol.61 no. 4, pp. 336-347.

[3] Bin Hashim, L. and Wan Mokhtar, W.N.H. (2005), "Trends and Issues in Preparing New Era Librarians and Information Professionals". Available at:http://www.lib.usm.my/elmu-eq uip/conference/Documents accessed October 2013

[4] Croenis, K. and Henderson, P. (2002), 'Electronic and Digital Librarian Positions: a Content Analysis of announcements from 1990 through 2000". Journal of Academic Librarianship, vol.28 no. 4, pp. 232-237

[5] Cullen, J. (2000), “A Review of Library and Information Service Job Advertisements: What Do they tell us about Work". Journal of Information Science, vol.26 no. 4, pp. 278-281.

[6] Feng, A. (no date), "Corporate Librarian 2.0: New Core Competencies". Available at: http://units.sla.org/division/dp $\mathrm{ht} /$ division_info/trvel-presentations/feng_essay.pdf accessed October 2013 .

[7] Holt, R. and Strock, A. (2005), "The entry-level Gap: Breaking into the Profession is harder than ever if you're fresh out of Library School". Library Journal, vol.130, no. 8, pp.36-38.

[8] King, D.L. (2007), "Basic Competencies of a 2.0 Librarian". Available at:http://www.davidleeking.com/2007/07/11/basic -competencies-of-a-20-librarian-take-2. accessed October 2013.

[9] Marion, L. (2001), "Digital Librarian, Cybrarian, or Librarian with Specialized Skills: who will staff Digital Libraries". Association of College and Research Libraries. $10^{\text {th }}$ National Conference. Available at: http://www.ala.org/ala/acrl/acrleve nts/marion.pdf accessed November 2013

[10] Mathews, J.M. and Pardue, H. (2009), "The Presence of IT Skills Sets in Librarian Position Announcements". College and Research Libraries, Vol.70, pp. 250-257.

[11] Partridge, H. et al. (2010)," The Contemporary Librarian: Skills, Knowledge and Attitudes required in a World of Emerging Technologies". Library and Information Science Research, vol. 32, no.4, pp. 265-271.

[12] Reeves, R. K. and Hahn, T.B. (2010), "Job Advertisements for Recent Graduates: Advising, Curriculum and Job-Seeking Implications". Journal of Education for Librarianship and Information Science, vol. 51, no.2, pp. 103-119

[13] Rehman, S. Ur. And Al Ansari, H. (2005),'Digital Marketplace and Library and Information Education in the GCC Member Nations: a Critical Review”. Library Review, vol. 52, no.4, pp.170-179.

[14] Sproles, C. and Ratledge, D. (2004), "an Analysis of Entry-Level Librarians ads Published in American Libraries, 1982-2002'. Available at:

http://southernlibrarianship.1 caap.org/content/v05n02/sprole sc01.htm.accessed November 2013

[15] Starr, J. (2004),"A measure of Change: Comparing Library Job Advertisements of 1993 and 2003". LIBRES: Library and Information Science Research Electronic Journal. Available at: http://libres.curtin.edu.au/libres14n2Starr_final.htm acces sed December 2013 